\title{
Gambaran Infeksi Protozoa Usus pada Murid Sekolah Dasar Negeri 22 Andalas Padang
}

\author{
Luois Joseph ${ }^{1}$, Rahmatini', Hasmiwati ${ }^{3}$ \\ ${ }^{1}$ Fakultas Kedokteran Universitas Andalas Padang \\ ${ }^{2}$ Bagian Farmakologi Fakultas Kedokteran Universitas Andalas Padang \\ ${ }^{3}$ Bagian Parasitologi Fakultas Kedokteran Universitas Andalas Padang
}

\section{A B S T R A C T}

\begin{abstract}
Latar Belakang. Infeksi protozoa usus merupakan salah satu masalah kesehatan di dunia dan sering terjadi pada muridmurid sekolah dasar.

Objektif. Penelitian ini bertujuan untuk mengetahui angka kejadian protozoa usus pada murid Sekolah Dasar Negeri 22 Andalas Padang.

Metode. Penelitian ini menggunakan desain penelitian deskriptif dan menggunakan teknik Consecutive Sampling. Penelitian dilakukan di Sekolah Dasar Negeri 22 Andalas, Padang dari bulan Juli 2017 hingga Oktober 2018 dan didapatkan sampel sebanyak 36 sampel tinja. Selanjutnya sampel diperiksa dengan menggunakan metode modifikasi pewarnaan Ziehl Neelsen.

Hasil. Dari penelitian ini didapat angka infeksi protozoa usus sebesar $13,9 \%$ dan jenis spesies protozoa usus yang ditemukan pada pemeriksaan tinja adalah Mixed infected (Cryptosporidium dan E. histolytica), Giardia lamblia, Cryptosporidium sp dan Blastocystis hominis. Protozoa usus ini ditemukan lebih tinggi pada perempuan dibandingkan laki-laki. Kesimpulan. Spesies lebih banyak ditemukan yaitu Giardia lamblia sebesar $40 \%$. Pencegahan infeksi perlu dilakukan, sehingga angka kesakitan dapat dikurangi.
\end{abstract}

Kata kunci: Protozoa usus, G.lamblia, E. histolytica, Cryptosporidium, B.hominis, Mixed infected

Background. Intestinal protozoa infection is a global health problem and usually happens among primary school students.

Objective. This research aims to know the prevalence of intestinal protozoa among students in Primary School State 22 Andalas, Padang.

Method. This descriptive study was conducted in Primary School State 22 Andalas, Padang from July 2017 until October 2018 to identify the protozoa in 36 feces samples chosen by consecutive sampling technique. Samples were examined by modified Ziehl Neelsen staining.

Result. The study showed that the rate of infection by intestinal protozoa was 13,9\% with Entamoeba histolytica, Giardia lamblia, Cryptosporidium sp, and Blastocystis hominis species found. This intestinal protozoan was found that higher frequency in girls compared to boys.
Conclusion. More intestinal protozoa species found were Giardia lamblia at $40 \%$. It is recommended that infection prevention protocol to be done to reduce the morbidity rate. Keywords: Intestinal protozoa, G.lamblia, E. histolytica, Cryptosporidium, B.hominis, Mixed infected

\section{Apa yang sudah diketahui tentang topik ini?}

Di Indonesia sendiri infeksi yang disebabkan oleh protozoa usus dapat ditemukan di daerah perkotaan ataupun daerah pedesaan. ${ }^{1}$ Spesies yang tergolong dalam protozoa usus yang dapat menimbulkan infeksi saluran pencernaan pada manusia yaitu dari kelas Rhizopoda adalah Entamoeba histolytica, kelas Mastigophora adalah Giardia lamblia dan kelas Sporozoa adalah Blastocystis hominis.

\section{Apa yang ditambahkan pada studi ini?}

Penelitian tentang prevalensi infeksi protozoa usus di Sumatera Barat masih sedikit. Penelitian yang dilakukan di SD Negeri 02 dan SD Negeri 12 Ulakan Tapakis Kabupaten Padang Pariaman dari 83 siswa $12 \%$ terinfeksi G. lamblia dan $3.6 \%$ terinfeksi Entamoeba histolytica. ${ }^{16}$

\section{CORRESPONDING AUTHOR}

Name: Luois Joseph

Phone: +6287772175482

E-mail: luois2003@gmail.com

\section{ARTICLE INFORMATION}

Received: September $23^{\text {rd }}, 2020$

Revised: October $15^{\text {th }}, 2020$

Available online: October $31^{s t}, 2020$ 


\section{Pendahuluan}

Infeksi protozoa usus merupakan salah satu masalah kesehatan di dunia terutama negaranegara berkembang, dimana tingkat pendidikan yang rendah dan iklim tropis merupakan faktor risiko infeksi protozoa usus. Prevalensi yang tinggi umumnya ditemukan di lingkungan sosioekonomi rendah dan sanitasi yang buruk. Di Indonesia sendiri infeksi yang disebabkan oleh protozoa usus dapat ditemukan di daerah perkotaan ataupun daerah pedesaan. ${ }^{1}$

Spesies yang tergolong dalam protozoa usus yang dapat menimbulkan infeksi saluran pencernaan pada manusia yaitu dari kelas Rhizopoda adalah Entamoeba histolytica, kelas Mastigophora adalah Giardia lamblia dan kelas Sporozoa adalah Blastocystis hominis. Entamoeba histolytica merupakan salah satu protozoa yang sering menjadi penyebab diare. ${ }^{2}$

Cryptosporidium sp, Cyclospora cayetanensis, Isospora belli dan Blastocystis hominis adalah protozoa usus oportunistik yang sering ditemukan akhir-akhir ini. Infeksi protozoa usus oportunistik ini dapat menimbulkan gejala yang bervariasi, mulai dari asimtomatik sampai diare berat persisten. Manifestasi klinis ini bergantung pada imunitas penderita. Hal ini dikarenakan peran sistem imun yang tidak mampu melawan infeksi protozoa. 4,5

WHO memperkirakan amoebiasis (infeksi oleh Entamoeba histolytica) merupakan penyebab paling umum kematian akibat infeksi parasit setelah malaria dan schistosomiasis, sekitar 50 juta orang di seluruh dunia menderita infeksi amoeba invasif setiap tahun dan sekitar 40.000 sampai 100.000 kematian setiap tahunnya. Tingkat kasus kematian global dilaporkan 2\% pada orang dewasa dan $25 \%$ pada murid-murid pada tahun 2012.6 Komplikasi terpenting dari amoebiasis adalah abses hati. Jika penderita tidak diobati dengan baik, proses lisis jaringan hati berlanjut sehingga abses pecah dan menyebar ke organ-organ sekitar seperti, paru, otak, kulit dan limpa.7 Giardiasis (infeksi oleh G. lamblia) terutama terjadi pada murid murid usia $<10$ tahun, dimana dapat terjadi gangguan absorpsi seperti, lemak, glukosa, laktosa, folat, karoten, vitamin B12. Pada beberapa penelitian dilaporkan bahwa murid-murid dengan infeksi kronis dapat mengalami gangguan pertumbuhan. ${ }^{4}$
Prevalensi infeksi protozoa usus di daerah tropis sekiar 50-60\% dari populasi yang ada di dunia. ${ }^{8}$ Prevalensi protozoa usus didapatkan data yang dilaporkan di negara maju seperti di Australia dan Inggris ialah G.lamlia $(0.2 \%$ $26.2 \%)$, Cryptosporidium spp $(0,1 \%-9,1 \%$ dari kasus), Entamoeba spp (0,2\% - 12,5\% dari kasus), dan C. Cayetanensis $(0,2 \%-4,3 \%$ dari kasus). Protozoa lain, seperti Blastocystis spp $(0.4 \%$ 18.1\%) dan Dientamoeba fragilis (0,4\% - 6,3\%) keduanya memiliki potensi untuk menyebabkan penyakit, namun dapat juga tidak menimbulkan gejala. Beberapa bukti dari literatur menunjukkan bahwa Blastocystis spp dan D. fragile memiliki prevalensi yang relatif tinggi di negara maju. ${ }^{9}$

Infeksi oleh protozoa usus lebih sering terjadi di negara berkembang. ${ }^{10}$ Penelitian di beberapa negara berkembang seperti Nepal, Ghana, Libya, Kenya dan Malaysia menunjukkan bahwa infeksi protozoa terbanyak disebabkan oleh G. lamblia, Entamoeba histolytica, B. hominis dan E. coli.11,12

Hasil penelitian di Malaysia menunjukkan angka kejadian terbanyak infeksi protozoa usus menurut usia terutama pada murid-murid yang duduk di bangku sekolah dasar yang berusia 712 tahun, dimana prevalensi infeksinya sekitar 15,1\%. Murid-murid pada usia sekolah lebih banyak melakukan aktifitas di luar rumah dimana mereka banyak bermain di kawasan yang terkontaminasi dengan feses manusia yang terinfeksi, disamping itu akibat kurangnya menjaga kebersihan, murid-murid juga sering mendapatkan infeksi melalui makanan yang telah terkontaminasi. ${ }^{13}$ Penelitian pada murid sekolah dasar di Ghana, angka kejadian infeksi protozoa usus berdasarkan jenis kelamin didapatkan pada murid laki-laki lebih banyak yaitu $58 \%$ sedangkan pada murid perempuan yaitu 30,8 \%.12

Di Indonesia prevalensi infeksi parasit usus tergolong tinggi terutama pada penduduk miskin, pendidikan yang rendah, hidup di lingkungan padat penghuni dengan sanitasi yang buruk, tidak mempunyai jamban serta fasilitas air bersih yang tidak mencukupi. ${ }^{14}$ Penelitian yang dilakukan di Jawa Tengah pada siswa Madrasah Ibtidaiyah (Sekolah Dasar) didapatkan dari 68 siswa 13,2\% terinfeksi $G$. lamblia. $^{15}$ Penelitian lain yang dilakukan pada murid panti asuhan di Bekasi protozoa yang paling banyak dijumpai ialah $B$. hominis (31\%), G. lamblia (7\%). ${ }^{14}$ 
Penelitian tentang prevalensi infeksi protozoa usus di Sumatera Barat masih sedikit. Penelitian yang dilakukan di SD Negeri 02 dan SD Negeri 12 Ulakan Tapakis Kabupaten Padang Pariaman dari 83 siswa 12\% terinfeksi G. lamblia dan 3.6\% terinfeksi Entamoeba histolytica. ${ }^{16}$ Penelitian lain yang dilakukan di rumah singgah Amanah kota Padang didapatkan infeksi yang disebabkan oleh G. lamblia lebih tinggi dibanding E. histolytica, yaitu G. Lamblia 37,88\% dan E. histolytica 7,41\% .17

Faktor risiko yang paling dominan dalam menimbulkan penularan penyakit diare terkait protozoa usus adalah, sarana air bersih yang dipakai sebagai sumber air tidak memenuhi syarat kesehatan, pembuangan kotoran berupa jamban yang tidak higienis dan tidak memenuhi syarat, pembuangan air limbah serta pengelolaan sampah yang tidak baik. ${ }^{18}$ Data Dinas Kesehatan Kota Padang tahun 2014-2015 menunjukkan angka kejadian diare tertinggi berada di Kecamatan Padang Timur, dimana untuk kasus diare pada semua umur berjumlah 730 kasus dan untuk kasus diare pada balita berjumlah 300 kasus. Berdasarkan data persentase penduduk yang menggunakan jamban sehat, Kecamatan Padang Timur masih rendah angka penggunaan jamban sehatnya yaitu 20,1\%. Akses terhadap air minum yang berkualitas, Kecamatan Padang Timur menempati posisi terendah di Kota Padang yaitu, 80,8\%.19 Data dari Puskesmas Andalas Padang menunjukkan bahwa Kelurahan Andalas merupakan kelurahan dengan angka kejadian diare tertinggi pada tahun 2014 yang berjumlah 202 kasus. $^{20}$

Berdasarkan observasi yang telah dilakukan peneliti di Kelurahan Andalas, sebagian besar murid-murid di daerah tersebut masih memiliki kebiasaan buang air besar di sungai, parit atau sawah depan rumah mereka yang mana tempat tersebut terkadang digunakan sebagai tempat menyuci baju ataupun peralatan rumah tangga. Selain itu tingkat sosio-ekonomi di daerah tersebut masih rendah.

SDN 22 Andalas merupakan salah satu sekolah yang terletak di Keluhuran Andalas Kecamatan Padang. Penelitian yang telah dilakukan oleh salah satu mahasiswa kedokteran Universitas Baiturrahmah di SDN tersebut didapatkan dari 24 murid yang mengembalikan pot tinja, ditemukan 12 murid terinfeksi oleh protozoa usus pada tahun 2013.21 Adapun protozoa usus yang ditemukan terdiri dari Entamoeba histolytica, G.lamblia, B.hominis dan E.nana. Berdasarkan hal diatas peneliti tertarik untuk melakukan penelitian mengenai gambaran infeksi protozoa usus pada murid SDN 22 Andalas, Padang.

\section{Metode}

Penelitian ini menggunakan desain penelitian deskriptif yang mana tujuannya adalah untuk mengetahui angka kejadian infeksi protozoa usus pada murid SDN 22 Andalas Padang 2018. Penelitian ini dilakukan di Sekolah Dasar Negeri 22 Andalas, Padang Provinsi Sumatera Barat dan Laboratorium Departemen Parasitologi Fakultas Kedokteran Universitas Andalas, Padang sebagai lokasi pemeriksaan sampel. Penelitian ini telah dilaksanakan sejak peneliti menentukan judul, menyusun proposal hingga seminar hasil yang berlangsung sejak bulan Juli 2017 hingga bulan Oktober 2018. Populasi dalam penelitian ini adalah semua siswa dan siswa kelas 1 dan 2 pada tahun 2018 di SDN 22 Andalas, Padang yang berjumlah 58 orang.

\section{Hasil}

Penelitian telah dilakukan di SD Negeri 22 Andalas, Padang dan dilakukan pemeriksaan sampel di Laboratorium Parasitologi Fakultas Kedokteran Universitas Andalas. Pengambilan sampel dilakukan mulai tanggal 14 Juli 2018 hingga 10 Agustus 2018. Populasi penelitian ini adalah murid kelas I dan II yang berusia 7-8 tahun yaitu sebanyak 58 orang. Dari 58 orang populasi yang diberikan botol tempat pengumpulan sampel tinja, hanya 36 siswa/i yang mengembalikan botol yang telah diisi dengan tinja. Penelitian ini dilakukan kerjasama dengan guru-guru yang bertugas di SD Negeri 22 Andalas Padang.

\section{Karakteristik Respoden}

Karakteristik responden dapat dilihat pada Tabel 1.

Tabel 1. Karakteristik Responden

\begin{tabular}{ccc}
\hline Karakteristik & Frekuensi & Persentase (\%) \\
\hline Jenis Kelamin & & \\
Laki-laki & 16 & 44,4 \\
Perempuan & 20 & 55,6 \\
\hline
\end{tabular}

Berdasarkan Tabel 1 dapat dilihat bahwa jumlah responden perempuan lebih banyak 
daripada jumlah responden laki-laki yaitu 20orang (55,6\%).

\section{Angka Kejadian Infeksi Protozoa Usus}

Distribusi frekuensi infeksi protozoa usus dapat dilihat pada Tabel 2 .

Tabel 2. Angka Kejadian Infeksi Protozoa Usus

\begin{tabular}{lcc}
\hline \multicolumn{1}{c}{$\begin{array}{c}\text { Kejadian Infeksi } \\
\text { Protozoa Usus }\end{array}$} & Frekuensi & Persentase (\%) \\
\hline Terinfeksi protozoa & 5 & 13,9 \\
usus & 31 & 86,1 \\
$\begin{array}{l}\text { Tidak terinfeksi } \\
\text { protozoa usus }\end{array}$ & & \\
\hline \multicolumn{1}{c}{ Total } & 36 & 100 \\
\hline
\end{tabular}

Berdasarkan Tabel 2 sebanyak 5 orang siswa/i $(13,9 \%)$ terdapat protozoa usus pada pemeriksaan tinja.

\section{Distribusi Protozoa Usus Berdasarkan Jenis Kelamin}

Hasil distribusi frekunsi infeksi protozoa usus berdasarkan jenis kelamin dan umur dapat dilihat pada Tabel 3.

Tabel 3. Distribusi Protozoa Usus Berdasarkan Jenis Kelamin

\begin{tabular}{lccccc}
\hline Responden & $\begin{array}{c}\text { Terinfeksi } \\
\text { Protozoa } \\
\text { Usus }\end{array}$ & \multicolumn{2}{c}{$\begin{array}{c}\text { Tidak } \\
\text { Terinfeksi } \\
\text { Protozoa Usus }\end{array}$} & Total \\
\cline { 2 - 4 } & f & \% & f & \% & \\
\hline Jenis & & & & & \\
Kelamin & & & & & \\
$\quad$ Laki-laki & 2 & 12.5 & 14 & 87.5 & 100 \\
$\quad$ Perempuan & 3 & 15 & 17 & 85 & 100 \\
Umur & & & & & \\
7 & 4 & 16.7 & 20 & 83.3 & 100 \\
8 & 1 & 8.3 & 11 & 91.7 & 100 \\
\hline
\end{tabular}

Berdasarkan Tabel 3 persentase responden perempuan lebih banyak mengalami infeksi protozoa usus. Infeksi protozoa usus ditemukan lebih banyak pada murid 7 tahun $(16,7 \%)$ dari umur 8 tahun $(8,3 \%)$.

\section{Distribusi Frekuensi Infeksi Protozoa Usus Berdasarkan Spesies Protozoa Usus}

Hasil distribusi frekuensi infeksi protozoa usus berdasarkan spesies protozoa usus yang ditemukan dapat dilihat pada Tabel 4 .
Tabel 4. Distribusi Protozoa Usus Berdasarkan Jenis Kelamin

\begin{tabular}{lccc}
\hline \multicolumn{1}{c}{ Spesies Usus } & Stadium & Frekuensi & $\begin{array}{c}\text { Persentase } \\
\text { (\%) }\end{array}$ \\
\hline Giardia lamblia & Ookista & 2 & 40 \\
$\begin{array}{l}\text { Cryptosporidium } \\
\text { Blastocystis } \\
\text { hominis20 }\end{array}$ & Ookista & 1 & 20 \\
$\begin{array}{l}\text { Mixed Infection } \\
\begin{array}{l}\text { Crypto \& E, } \\
\text { histolytica) }\end{array}\end{array}$ & Trofozoit & 1 & 20 \\
Total & & & 20 \\
\hline
\end{tabular}

Berdasarkan Tabel 4 dapat dilihat jenis protozoa usus yang ditemukan adalah Entamoeba histolytica, Cryptosporidium sp, Giardia lamblia dan Blastocytosis hominis. Spesies protozoa usus yang lebih banyak ditemukan adalah Giardia lamblia (40\%)

\section{Pembahasan}

\section{Angka Kejadian Infeksi Protozoa Usus pada Murid SD Negeri 22 Andalas.}

Hasil pemeriksaan tinja yang telah dilakukan pada murid SD Negeri 22 Andalas, Padang ditemukan protozoa usus pada 5 sampel $(13,9 \%)$ dari tinja yang diperiksa. Penelitian lain yang telah didapatkan hasil yang tidak jauh berbeda, yaitu ditemukan protozoa usus pada murid kelas I-VI SD Negeri 02 (12\%) dan SD Negeri Ulakan Tapakis $(3,6 \%)$ di Kabupaten Padang Pariaman pada sampel tinja yang diperiksa. ${ }^{16}$ Hal ini terjadi karena kemungkinan lingkungkan kawasan sanitasi dan personal hygiene di sekolah tersebut lebih baik daripada SDN 22 Andalas, Padang

Prevalensi ini lebih rendah dibandingkan dengan penelitian yang menemukan 15,1\% murid sekolah berusia 7-12 tahun ditemukan protozoa usus pada pemeriksaan tinjanya. ${ }^{13} \mathrm{Hal}$ ini terdapat karena kemungkinan beda karakteristik sampel yaitu usia murid yang berbeda.

Penelitian serupa juga telah didapatkan angka kejadian infeksi protozoa usus yang lebih tinggi yaitu 27,9\% dari 68 sampel yang diperiksa. ${ }^{15}$ Tingginya temuan protozoa usus pada penelitian ini dikarenakan sampel yang digunakan adalah murid kelas 1-6 MII yang disertai diare. ${ }^{15}$

\section{Distribusi Frekuensi Infeksi Protozoa Usus Berdasarkan Jenis Kelamin}

Pada angka kejadian infeksi protozoa usus lebih tinggi pada perempuan (15\%) dibandingkan laki-laki (12,5\%). Kecenderungan terjadinya 
infeksi protozoa usus pada seseorang adalah status gizi, umur, hygiene perorangan, sanitasi lingkungan, sosial ekonomi, serta adanya komplikasi dengan infeksi parasit atau bakteri lain sedangkan faktor jenis kelamin tidak mempengaruhi infeksi protozoa usus. ${ }^{13}$ Tingginya infeksi protozoa usus yang terjadi pada perempuan dalam penelitian ini mungkin terjadi karena jumlah responden perempuan lebih banyak daripada laki-laki dan laki-laki lebih bagus menjaga personal hygiene daripada perempuan.

\section{Distribusi Frekuensi Infeksi Protozoa Usus Berdasarkan Spesies Protozoa Usus}

Pada penelitian ini terdapat 4 spesies protozoa usus yang ditemukan, berdasarkan hasil pemeriksaan sampel tinja murid di SD Negeri 22 Andalas, jenis protozoa yang ditemukan yaitu spesies Giardia lamblia (40\%), Cryptsporidium (20\%), Blastocytosis hominis (20\%) dan Mixed Infection (20\%). Penelitian yang dilakukan oleh Ortega (2010) menunjukkan angka kejadian infeksi protozoa oportunistik di Amerika Latin pada murid sekolah dasar cukup rendah, yaitu sebesar $4 \%{ }^{4,31,3}$

Spesies-spesies ini biasanya ditularkan melalui air yang tercemar oleh kista, kista ini sulit untuk dibunuh dengan klorinisasi. Kemungkinan lain sumber infeksi protozoa usus adalah sumber air minum yang telah terkontaminasi kista spesies tersebut karena kista protozoa baru dapat mati pada suhu $50{ }^{\circ} \mathrm{C}$ atau pada keadaan kering. ${ }^{4}$ Sumber lain adalah makanan yang tercemar, lingkungan buruk dan sanitasi perorangan buruk.

Berdasarkan penelitian lain mengemukakan bahwa E. histolytica merupakan spesies terbanyak yang ditemukan pada murid yaitu sebanyak 30\% dari total semua parasit usus yang ditemukan di Iran.23 Penelitian serupa yang menunjukkan bahwa Cryptosporidium dan E. histolytica merupakan protozoa usus terbanyak $15,1 \%$ yang ditemukan pada murid berusia 7-12 tahun di Malaysia. ${ }^{13,22}$

Penelitian yang dilakukan di SD Negeri 22 Andalas didapatkan hasil yang berbeda dari penelitian yang telah dilakukan sebelumnya karena disebabkan oleh faktor karakteristik sampel yang digunakan, faktor lingkungan dan personal hygiene. Infeksi protozoa usus ini dapat terjadi apabila tertelan kista yang bisa menyebabkan kontaminasi makanan ataupun sumber air minum sehingga menjaga kebersihan perorangan dan lingkungan.

\section{Simpulan}

Berdasarkan penelitian yang telah dilakukan maka didapatkan kesimpulan sebagai angka kejadian infeksi protozoa usus pada murid kelas I dan II SD Negeri 22 Andalas, Padang adalah sebanyak $13,9 \%$. Jumlah angka kejadian protozoa usus pada perempuan lebih tinggi dibandingkan laki-laki. Jenis spesies protozoa usus yang ditemukan pada pemeriksaan tinja adalah $E$. histolytica, G. lamblia, Cryptosporidium $s p$, dan $B$. hominis. Spesies yang lebih banyak adalah $G$. lamblia yaitu $40 \%$.

\section{Ucapan Terima Kasih}

Ucapan terima kasih peneliti sampaikan kepada seluruh pihak yang turut membantu dalam menyelesaikan penelitian ini.

\section{Daftar Pustaka}

1. Anorital, Dewi RM, Ompusunggu S. Distribusi Parasit Usus Protozoa di Kabupaten Hulu Sungai Utara Kalimantan Selatan. Suplemen Media Penelitian dan Pengembangan Kesehatan. 2010;20:8-18.

2. Garcia LS, editor. Diagnostic Medical Parasitology. 5th ed. ASM Press; 2007.

3. Osman M, Safadi D El, Cian A, Benamrouz S, Nourrisson C, Pereira B, et al. Prevalence and Risk Factors for Intestinal Protozoan Infections with Cryptosporidium, Giardia, Blastocystis, and Dientamoeba among Schoolchildren in Tripoli, Lebanon. PLoS Negl Trop Dis. 2016;10(3).

4. L Susanto, Gandahusada S. Coccidia. In: Susanto I, Ismid IS, Sjarifuddin PK, Sungkar S, editors. Parasitologi Kedokteran. 4th ed. Jakarta: Balai Penerbit FKUI; 2008.

5. Sears CL, Kirkpatrick BD. Cryptosporidiosis and Isosporiasis. In: Gillespie SH, Pearson RD, editors. Principles and Practice of Clinical Parasitology. New York; 2001. p. 139-59.

6. Food and Drug Administration. Handbook of foodborne pathogenic microorganisms and natural toxins. Department of Health and Human Services (2012) (5): 231-44.

7. Soedarto. Buku ajar parasitologi kedokteran. Jakarta : CV Sagung Seto (2011) (3) : 287-99.

8. Renhaleksmana E, Sutarti E, Wijayanti MA. Prevalence and Risk Factors of intestinal protozoan infection in HIV/AIDS in Dr. Sardjito General Hospital Yogyakarta. Tropical Medicine Journal (2011) 1(1): 23-30.

9. Fletcher SM, Stark D, Harkness J, Ellis J. Enteric protozoa in the developed world: A Public health perspective. Clin Microbiol Rev (2012) (3) : 420-49.

10. Haque R. Human intestinal parasite. J Health Popul Nutr (2008) (4): 387-91.

11. El Ammari NE, Nair GA. Critical evaluation of the intestinal protozoan parasites among Libyan and 
other African Residents of Al-Khoms, Libya. Journal of Entomology and Zoology Studies (2015) 3(2): 426.

12. Walana W, Samuel CKT, Philip T, Juventus BZ. Prevalence of intestinal protozoan infestation among primary school children in urban and peri-urban communities in Kumasi, Ghana. Science PG (2014) $2(2): 52-7$.

13. Yusof $H$, Ghani MKA. Giardiasis di kalangan muridmurid orang asli di Pos Lejang, Pahang. Jurnal Sains Kesihatan Malaysia (2009) 7 (2) : 97-102.

14. Darnely,. Infeksi parasit usus pada murid panti asuhan di Pondok Gede Bekasi. J Indon Med Assoc (2011) 61 (9) : 307 - 50.

15. Widyastuti IK. Prevalensi infeksi amebiasis pada siswa madrasah ibtidaiyah islamiyah Desa Simbang Wetan Kecamatan Buaran Pekalongan, Jawa Tengah. Skripsi pada Fakultas Kedokteran Universitas Diponegoro (2011).

16. Julianti F. Hubungan infeksi protozoa intestinal dengan status gizi murid sekolah dasar di Kecamatan Ulakan Tapakis Kabupaten Padang Pariaman. Skripsi pada Fakultas Kedokteran Universitas Andalas (2015).

17. Nurhayati. Gambaran infeksi protozoa intestinal pada murid binaan rumah singgah amanah Kota Padang. Majalah Kedokteran Universitas Andalas (2010) 30(1) : 52-8.

18. Muhajir NF, Herdiana E, Mulyaningsih B. Kajian infeksi protozoa usus pada pasien diare di bagian rawat inap RSUD Panembahan Senopati Bantul Yogyakarta. Thesis Pada Fakultas Kedokteran Universitas Gajah Mada (2015).

19. Dinas Kesehatan Kota Padang. Laporan Tahunan 2013 edisi 2014. Padang 134-39.

20. Puskesmas Andalas Padang. Data kasus diare puskesmas Andalas Padang tahun 2014. Padang (2015).

21. Wani Devita Gunardi. Mengetahui Infeksi Protozoa Usus pada Anak SDN 22 Andalas, Padang. Skripsi pada Fakultas Kedokteran Baiturrahmah. 2013.

22. Nowak P, Mastalska K, Loster J. Entamoeba. Histolytica - Pathogenic Protozoan of the Large Intestine in Humans. J Clin Microbiol Biochem Technol (2015) 1(1):10-7.

23. Tanyuksel M, William A. Petri J. Laboratory Diagnosis of Amebiasis. Clin Microbiol Rev (2003) 16(4):71326. 